\title{
COM \\ Follow the scientists? How beliefs about the practice of science shaped COVID-19 views
}

\section{Thomas G. Safford, Emily H. Whitmore and Lawrence C. Hamilton}

\begin{abstract}
"Follow the science" became the mantra for responding to COVID-19 pandemic. However, for the public this also meant "follow the scientists", and this led to uneasiness as some viewed scientists as not credible. We investigate how beliefs about the way scientists develop their findings affect pandemic-related views. Our analysis shows that beliefs about scientists' objectivity predict views regrading coronavirus-related risks, behavioral changes, and policy priorities. While political party identity also predicts views about COVID-19-related concerns, these vary by political leaders whose approaches embraced versus dismissed science-based strategies, highlighting the importance of perceptions of scientists in shaping pandemic-related attitudes and beliefs.
\end{abstract}

\section{Keywords}

DOI

Scientists and the COVID-19 pandemic
Public understanding of science and technology; Risk communication; Science and policy-making

https://doi.org/10.22323/2.20070203

Submitted: 17th June 2021

Accepted: 1st September 2021

Published: 15th November 2021

The COVID-19 pandemic dominated headlines throughout 2020 and scientists were inextricably connected to discussions of threats from the coronavirus. "Follow the science" was an ever-present part of the discourse and this mantra became the foundation for pandemic-related health policies in the United States and around the globe. Government officials repeatedly asked the public to comply with science-based recommendations for combating the virus and scientists became visible health policy advocates. Nonetheless, as policy choices forwarded by scientists clashed with core societal values such as individual liberty and the prioritization of economic well-being, public scrutiny of scientists intensified.

While scientists dominating headlines was something new during the COVID-19 crisis, the questioning of scientists' role in policymaking was not; rather the pandemic appears to have accelerated the erosion of scientific authority that had already been trending prior to the coronavirus outbreak [Gauchat, 2012; Merkley, 2020; Motta, 2018a; Motta, 2018b; Safford, Whitmore and Hamilton, 2020]. Previous 
studies demonstrate that trust in science and the perceived credibility of scientists can influence views about science-related issues and policy recommendations [Chryssochoidis, Strada and Krystallis, 2009; Iyengar and Massey, 2019; Kellstedt, Zahran and Vedlitz, 2008; Millstone and van Zwanenberg, 2000; Yamamoto, 2012]. Building on these findings, recent scholarship illustrates that a range of social factors influence attitudes and beliefs about COVID-19-related concerns [Adolph et al., 2021; Agley and Xiao, 2021; Aksoy, Eichengreen and Saka, 2020; Algara et al., 2021; Brzezinski et al., 2021; Calvillo et al., 2020; Hamilton and Safford, 2021a; Hamilton and Safford, 2021b; Hamilton and Safford, 2021c; Safford and Hamilton, 2020]. However, to what extent beliefs about the integrity and objectivity of scientists relate to beliefs about COVID-19 and support for public health interventions remains an open question.

We utilize data from the Granite State Panel Survey (GS Panel) in the U.S. state of New Hampshire to investigate how public perceptions of scientists along with social background variables affect pandemic-related beliefs. Findings confirm previous investigations showing the importance of political party affiliation in predicting views about the coronavirus [Allcott et al., 2020; Gadarian, Goodman and Pepinsky, 2021; Green et al., 2020; Grossman et al., 2020; Hamilton and Safford, 2021a; Hamilton and Safford, 2021b; Hamilton and Safford, 2021c; Kreps, Prasad et al., 2020]. However, we also find general beliefs about the objectivity of scientists are an important predictor, and this discovery highlights the importance of the public's understanding of scientists' practices and integrity in shaping views about COVID-19. For many in the public calls to "follow the science" may be interpreted as "follow the scientists", and if scientists are perceived as biased or not credible, this refrain may lead to apprehension rather than encourage compliance with science-based public health recommendations. Thus, identifying factors that are undermining confidence in science and scientists and communicating with the public about how science is practiced and could help engender support for science-based initiatives seeking to stem the COVID-19 pandemic.

The social bases of perceptions of scientific practice
In the wake of global pandemics, anxiety spreads and the public are often uncertain who they can trust for information about health threats and appropriate responses. Trust is multidimensional [Mayer, Davis and Schoorman, 1995] and those investigating trust in scientists have focused on the importance of beliefs about scientists' capabilities as well as their character [Fiske and Dupree, 2014; Renn and Levine, 1991]. Recent scholarship suggests that competence, benevolence, openness, and integrity are four critical dimensions of trust in scientists [Besley, Lee and Pressgrove, 2021].

The degree to which scientists conveying information related to COVID-19 are perceived as competent, benevolent, open, and having integrity all likely affect assessments of their trustworthiness. However, a 2019 study by the Pew Research Center highlights considerable skepticism among Americans about the integrity of scientists and how this may relate to concerns about scientists' involvement in policy issues [Funk et al., 2019]. They found 35\% of respondents believed the scientific method can be used to produce any conclusion the researcher wants, and $44 \%$ of respondents indicated that scientists' judgements are just as likely to be biased as other people's [Funk et al., 2019]. These results point to the importance of 
assessing how beliefs about scientists' integrity may influence views about the COVID-19 pandemic.

Scientists view the practice of science as systematic, rigorous, and fundamentally objective and believe results should be evaluated based on adherence to established methodological procedures and not on the character of researchers [De Vries, Anderson and Martinson, 2006; National Academies of Sciences, Engineering, and Medicine (NASEM), 2009; Sieber and Tolich, 2013]. While uncertainty is considered "normal" within the scientific community, lay people can be uncomfortable with the caveats and approximations used by scientists when conveying findings, leading some to question their integrity. Relatedly, disinformation about how science should be practiced, and misrepresentations of scientific certainty have contributed to the erosion of scientists' credibility particularly during the COVID-19 crisis [Agley and Xiao, 2021; Chryssochoidis, Strada and Krystallis, 2009; Iyengar and Massey, 2019; Millstone and van Zwanenberg, 2000; Prasad, 2021]. This has practical implications as adherence to coronavirus mitigation measures and public health recommendations have been found to be lower among those with decreased confidence in science and scientists [Brzezinski et al., 2021; Calvillo et al., 2020; Eichengreen, Aksoy and Saka, 2021; Sanchez and Dunning, 2021].

Also, as science becomes more enmeshed with policy, lay people who are not familiar with the norms of scientific inquiry often expect presentation of alternative explanations or want to draw their own inferences rather than have scientists tell them the meaning of information [Post, Bienzeisler and Lohöfener, 2021]. Similarly, when scientific findings are marshalled to justify one policy option or the public is told simply to adhere to scientists' recommendations, their disinterestedness may be questioned [Bauer and Jensen, 2011; Besley and Nisbet, 2013; Fiske and Dupree, 2014; Hamilton and Safford, 2020a; Hamilton and Safford, 2020b; Leiserowitz et al., 2013; Motta, 2018a; Motta, 2018b; Safford, Hamilton and Whitmore, 2017; Safford, Whitmore and Hamilton, 2020; Vraga et al., 2018; Yamamoto, 2012]. Finally, communication styles are also important in shaping perceptions, with recent studies demonstrating how the use of aggressive language can undermine scientists' credibility [König and Jucks, 2019; König and Breves, 2021].

In the U.S., the increasingly ideological nature of policy making has amplified these trends, such that science-related issues are more and more viewed through a political rather than technical lens [Brewer and Ley, 2013; Hamilton, Hartter and Saito, 2015; Hamilton and Safford, 2021c; Kreps and Kriner, 2020; McCright and Dunlap, 2011; Safford, Norman et al., 2014; Sides, Tausanovitch and Vavreck, 2020]. As contentious health and environmental policies can hinge on scientific understanding, opponents have also forwarded anti-intellectual arguments, and focused on undermining the credibility of scientists to derail these initiatives [Chryssochoidis, Strada and Krystallis, 2009; Iyengar and Massey, 2019; Merkley, 2020; Millstone and van Zwanenberg, 2000; Motta, 2018a]. With scientists' public-facing behaviors and communication taking center stage, science-related assessments become less about the rigor of scientific inquiry and more about the character of scientists themselves and how science is being used for policy advocacy [Collins and Evans, 2002; Brossard and Nisbet, 2007; Gieryn, 1983; Post, Bienzeisler and Lohöfener, 2021; Wynne, 1995]. 
At the outset of the coronavirus pandemic, significant majorities of the U.S. public supported scientific leadership in guiding health policies focused on combating the virus [McFadden et al., 2020]. However, subsequent research more closely mirrors the aforementioned studies of the science-politics nexus, showing political ideology shaping beliefs about risks associated with COVID-19, trust in U.S. Centers for Disease Control (CDC) for information about the virus, and appropriate responses to the pandemic, illustrating the potential perils associated with too closely intermeshing science and politics [Allcott et al., 2020; Calvillo et al., 2020; Funk et al., 2019; Gadarian, Goodman and Pepinsky, 2021; Grossman et al., 2020; Hamilton and Safford, 2020a; Hamilton and Safford, 2020b; Hamilton and Safford, 2021b; Hamilton and Safford, 2021a; Safford and Hamilton, 2020; Sides, Tausanovitch and Vavreck, 2020]. Building on the extant literature, this study focuses on establishing to what extent public perceptions of scientists' practices and objectivity relate to beliefs about COVID-19 and assessments of governmental responses to the pandemic.

Research design and methods
Our data come from two waves of the Granite State Panel survey (GS Panel), a probability-based web panel survey administered by the University of New Hampshire Survey Center. GS Panel respondents are recruited randomly from New Hampshire phone numbers and panel members receive web-based surveys by email. We utilize data from two 2020 GS Panel surveys that included COVID-19 related questions - March $(n=650)$ and July $(n=959)$. As panel participants are chosen randomly from a pool of possible respondents, the July survey included 208 individuals who also partook in the March panel. Excluding the repeat panel participants does not alter our findings, but creates less precise estimates, so we opted to use the full sample for our analyses here.

Table 1 describes variables utilized in this study and includes descriptive statistics as well as coding for regression analysis. Background demographic characteristics include four variables, Gender, Age, Education, and Party. Gender is dichotomized $(0,1)$ for male and female. A small number of respondents chose non-binary

Table 1. Variable definitions with codes and weighted summary statistics.

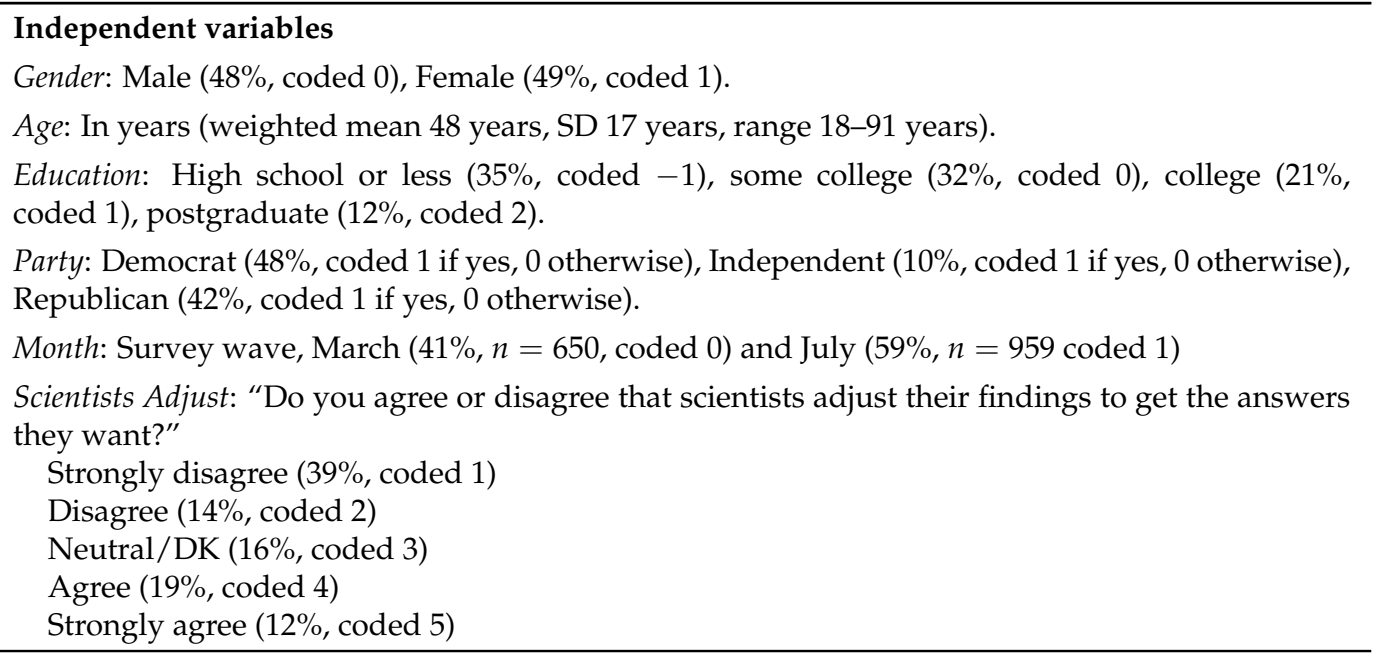


Table 1. Continued from the previous page.

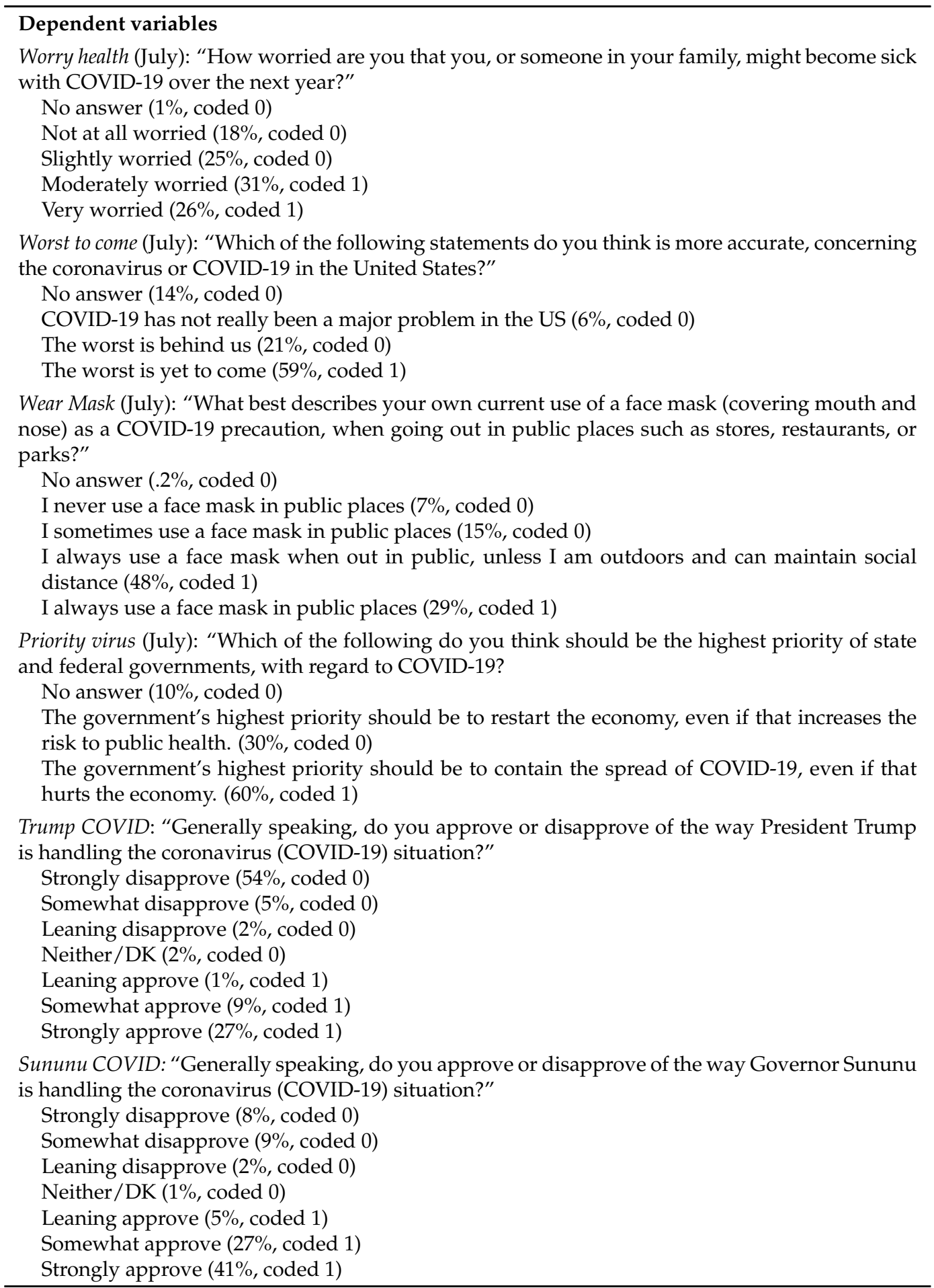

identities, but these were too few for analysis. Education is broken out in four values and centered from -1 to +2 , with technical school or some college at 0 , for interaction effect purposes. Other studies show monotonic and approximately linear effects of such education indicators on science-related dependent variables [Fogg, Hamilton and Bell, 2020; Hamilton and Fogg, 2019; Hamilton and Safford, 2020a; Safford, Whitmore and Hamilton, 2020]. 
Party includes self-identified political party affiliation with Democrats, Independents and Republicans. A limited number of respondents, too few for analysis, chose other parties or no affiliation. We also included Month as an independent variable to enable testing for possible changes between March and July 2020 for questions that were asked on both waves of the survey. Finally, the Scientists Adjust variable asked participants the extent to which they agree that scientists adjust their findings to get the answers they want. Using this question as an independent variable cast a light on how general beliefs about way scientists develop their findings relate to more specific views regarding COVID-19.

The six dependent variables outlined in Table 1 enable consideration of GS Panel participants' views about COVID-19 and governmental responses to the pandemic. The first four, Worry Health, Worst to Come, Wears Mask, and Priority Virus were asked only on the July 2020 GS Panel, while the final two, Trump COVID and Sununu COVID, were included both in March and July. Worry Health queries respondents about the degree to which they worry that they or members of their family may become sick with COVID-19; Worst to Come assesses whether respondents believe that, for the U.S., the worst of the pandemic was yet to come; Wears Mask queries if respondents adopted the key health-safety measure of wearing a mask to limit the spread of the coronavirus; Priority Virus homes in on the policy arena and gauges whether respondents believe the government's highest priority should be containing COVID-19 or restarting the economy. Finally, the Trump COVID and Sununu COVID questions assess the degree to which respondents approve of then President Donald Trump's and New Hampshire Governor Chris Sununu's handling of the COVID-19 situation.

All dependent variables outlined in Table 1 are dichotomized to focus analytically on the most substantively important responses; their $(0,1)$ coding is outlined in the table. Binomial logit regression modeling offers parsimony and interpretative advantages over multi-category methods such as ordered or multinomial logit, although our preliminary analyses confirmed that these different approaches lead to similar conclusions.

Connecting views about scientists and the COVID-19 pandemic
The objective of this study is to investigate how concerns about bias and the objectivity of scientists may affect views about the coronavirus pandemic. Earlier work with the Scientists Adjust question, on a 2016 nationwide survey, found that it predicted views about other science-related issues such as climate change [Safford, Whitmore and Hamilton, 2020], and also affected trust in science agencies such as the U.S. Centers for Disease Control and Prevention (CDC) regarding the 2016 Zika virus pandemic [Safford, Hamilton and Whitmore, 2017].

Bringing this Scientists Adjust variable into the time of COVID-19, the GS Panel results in Table 1 show 39\% strongly disagreed and 14\% disagreed with the statement, "Scientists adjust their findings to get the answers they want", illustrating that most respondents do not believe scientists adjust their results to get the answers they desire. Nonetheless, 12\% strongly agreed and 19\% agreed with this statement, with the remaining $16 \%$ indicating they were unsure. The fact that nearly a third of GS Panel respondents agreed that scientists adjust their findings suggests many in the public have doubts about scientists' objectivity, raising the question as to whether such a belief may affect views about COVID-19. 
We examine how agreement that scientists adjust their results affects views about threats from the coronavirus as well as individual level and policy responses.

Public perceptions of COVID-19 show variation as well. One of the most important roles scientists have had during the pandemic is fostering awareness of the serious health risks associated with the coronavirus. The GS Panel survey asked respondents how worried they were that they or someone in their family might become sick with COVID-19 over the next year. $57 \%$ of respondents indicated they were either very or moderately worried that they or a family member might contract the coronavirus. Similarly, 59\% of panel respondents (accurately) thought that the worst of the pandemic was yet to come, as opposed to the worst being behind us, or believing COVID-19 had not been a problem. Both questions highlight divisions in how respondents viewed the risks from the virus to them personally and to the U.S. in general.

When asked to describe their current use of a face mask as a precaution against COVID-19, 76\% of GS Panel respondents stated they either always used a face mask in public places or always used a face mask except when outdoors. These results show high compliance with both the federal and N.H. public health guidance at the time that required wearing face coverings to curb the spread of the virus. Finally, respondents were also queried about coronavirus policy priorities. During the summer of 2020, there was increasing debate in the U.S. about whether government should prioritize restarting the economy or maintain the focus on containing the spread of COVID-19. $60 \%$ of respondents indicated the government's highest priority should be to contain the spread of COVID-19, even if that hurts the economy. Conversely $40 \%$ of respondents stated the highest priority should be to restart the economy, even if that increases the risk to public health; we again find a considerable split.

Figure 1 charts the associations between four COVID-19 items - Worry Health, Worst to Come, Wear Mask, and Priority Virus - and belief that scientists adjust their findings to get answers they want (Scientists Adjust). In each case we see steep and statistically significant $(p<0.001)$ gradients, in which respondents who questioned scientists generally also tended to reject science based COVID assessments, behavioral guidance, and policy choices. For example, panel $1 \mathrm{~d}$ shows that $95 \%$ of those who strongly disagree that scientists adjust their findings (i.e., believe in scientists' integrity), think that controlling the virus should be the government's priority. Conversely, only $14 \%$ of those who strongly agree that scientists adjust their findings (i.e., those who doubt scientists' integrity) prioritize controlling the virus. Lower regard for scientists is similarly related to concern about personal or family health (panel 1a); dismissal of warnings that the worst of the pandemic was yet to come (panel 1b); and compliance with mask-wearing advice (panel 1c).

Two further COVID-19-related items appeared on both the July and March 2020 surveys, asking respondents whether they approved of how President Trump or N.H. Governor Sununu were handling the pandemic (Trump COVID and Sununu COVID). Panels $2 \mathrm{a}$ and $2 \mathrm{~b}$ in Figure 2 chart the percentages approving of Trump or Sununu, broken down by responses to the Scientists Adjust question, which again predict COVID-issue responses. Overall approval of how President Trump was handling the pandemic was low, 37\%, compared with 73\% for Governor Sununu. Trump approval also was more strongly related to distrust in scientists, ranging 
(a) Worried about own or family's health

(b) Worst is yet to come
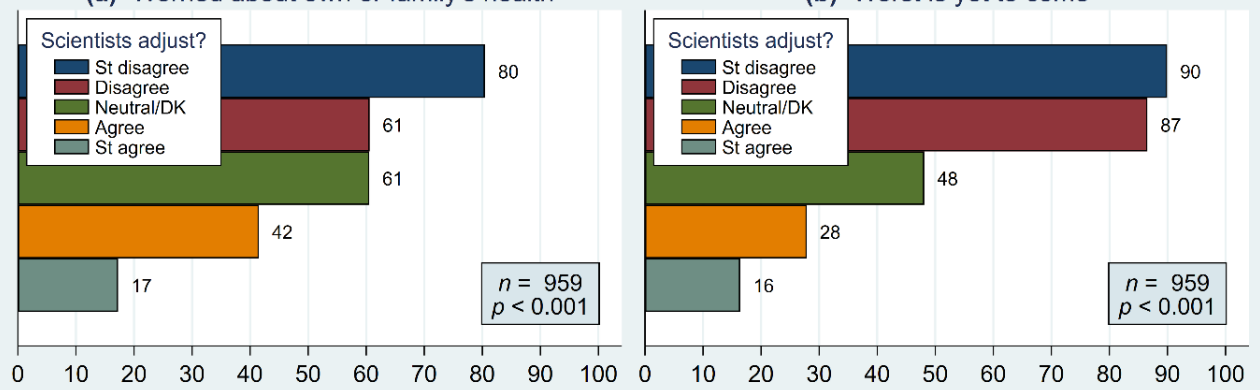

(c) Usually/always wear mask in public

(d) Controlling virus government's highest priority

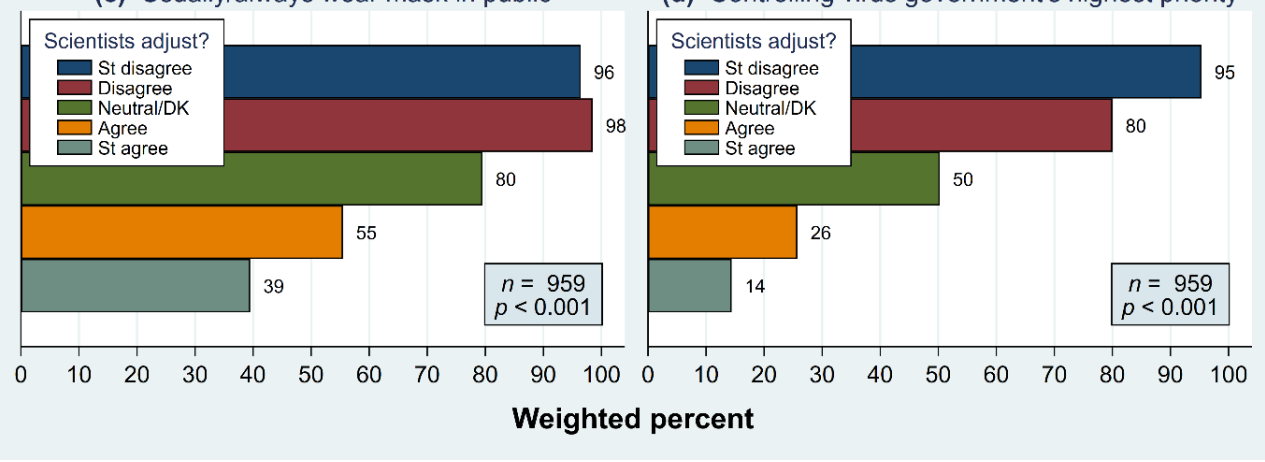

Figure 1. COVID-19 responses (Worry Health, Worst to Come, Wear Mask, and Priority Virus) by whether respondent agrees that scientists adjust findings to get answers they want (Scientists Adjust), from July 2020 GS Panel survey. Each graph shows the number of observations and weighted $t$-test probability for that relationship (all $p<0.001$ ).

(a) Approve Pres. Trump's handling coronavirus

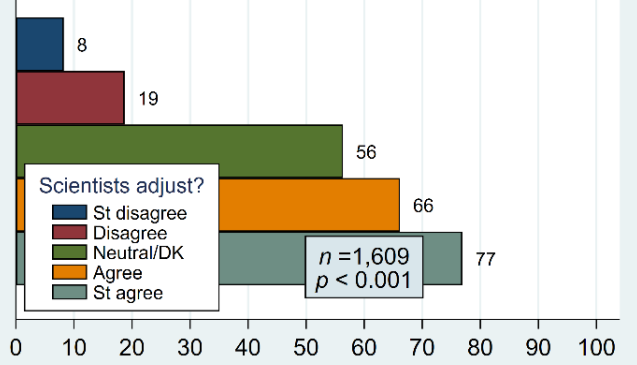

(c) Approve Pres. Trump's handling coronavirus

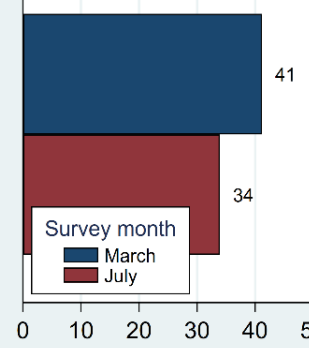

(b) Approve Gov. Sununu's handling coronavirus

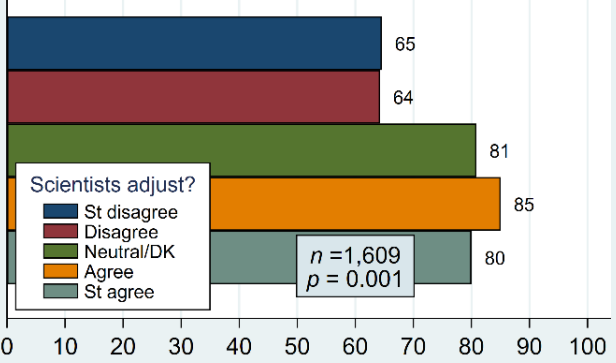

(d) Approve Gov. Sununu's handling coronavirus

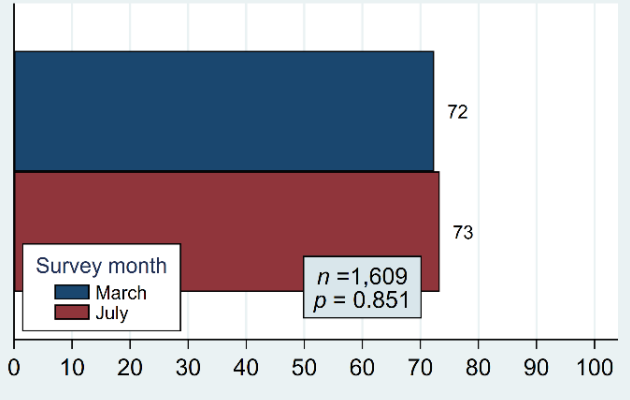

Weighted percent

Figure 2. Approval of President Trump's and Governor Sununu's handling of COVID-19 situation (Trump COVID, Sununu COVID) by whether respondent agrees that scientists adjust findings to get answers they want (Scientists Adjust), pooling March and July 2020 GS Panel survey. Each graph shows the number of observations and weighted $t$-test probability for that association. 
from $8 \%$ approval among those who strongly disagree that scientists adjust findings, up to $77 \%$ approval among those who strongly agree $(p<0.001)$. Approval of Governor Sununu exhibits a milder but still significant $(p=0.001)$ association with distrust of scientists.

Panels $2 \mathrm{c}$ and $2 \mathrm{~d}$ test whether approval of the political leaders' approach to the pandemic changed between our March and July surveys. Approval of Governor Sununu's handling of the coronavirus crisis was stable and high, at $72 \%$ or $73 \%$ $(p=0.851)$. Support for President Trump started lower, then further declined from $41 \%$ to $34 \%(p=0.187)$.

The bivariate results in Figure 1 depict strong zero-order relationships between Scientists Adjust and four COVID-related questions included in the July survey. Scientists Adjust also strongly correlates with political party affiliation (polychoric correlation 0.72), however, and to a lesser degree with other respondent characteristics, so the bivariate associations in Figure 1 might turn out to be spurious. Testing that possibility, Table 2 enters Scientists Adjust together with respondent gender, age, education, and political party as predictors of four COVID items: Worry Health, Worst to Come, Wear Mask and Priority Virus. The table contains odds ratios from logit regressions, describing multiplicative effects on the dependent variables. For example, the odds of thinking the worst of the pandemic was yet to come were $94 \%$ lower (multiplied by 0.060) among Republicans, compared with Democrats (the base category). Odds ratios below 1 correspond to "negative" effects, decreasing the odds of a respondent worrying about contracting COVID-19, believing that the worst of the pandemic is yet to come, usually wearing a mask, or believing controlling the virus should be the priority versus restarting the economy. Conversely, odds ratios above 1 correspond to "positive" effects, increasing the odds of those responses.

Table 2. Predictors of participant response to four COVID-19 items. Odds ratios are from weighted logit regressions ( $n=899$; July 2020 GS Panel survey).

\begin{tabular}{lcccc}
\hline & Worry Health & Worst to Come & Wear Mask & Priority Virus \\
\hline Gender & 1.101 & .611 & .919 & .751 \\
Age & $1.021^{*}$ & 1.023 & $1.079^{* * *}$ & 1.000 \\
Education & .995 & .634 & $.494^{*}$ & $.445^{* *}$ \\
Party & & & & \\
$\quad$ Democrat (base) & & & & \\
$\quad$ Independent & 1.801 & .483 & .394 & $.150^{* *}$ \\
$\quad$ Republican & $.285^{*}$ & $.060^{* * *}$ & $.060^{* * *}$ & $.022^{* * *}$ \\
Education $\times$ Party & & & & \\
$\quad$ Democrat (base) & & & & 1.331 \\
Independent & $.349^{*}$ & .813 & 1.280 & $2.607^{*}$ \\
Republican & .815 & $2.009^{*}$ & $3.240^{* *}$ & $.382^{* * *}$ \\
Scientists Adjust & $.595^{* * *}$ & $.466^{* * *}$ & $.357^{* * *}$ & $19.30^{* * *}$ \\
F statistic & $17.38^{* * *}$ & $19.36^{* * *}$ & $7.02^{* * *}$ & \\
\hline *** $p<.001,{ }^{* *} p<.01,{ }^{*} p<.05$. & & &
\end{tabular}


COVID-19 has had disproportionate impacts on the elderly, so it is unsurprising that age is a significant predictor for the two risk-related variables. Older individuals have increased odds of worrying that they or a family member will contract the coronavirus and are also more likely to wear a mask to protect against spreading the virus. Level of education also has significant effects, with more educated individuals having lower odds of prioritizing curbing the spread of the virus over re-starting the economy and always wearing a mask in public. Because the models also include education $\times$ party interactions (explained below), these main effects of education are contingent. They describe effects of education among Democrats, the base category of party; but only with other things (most importantly, beliefs about scientists) being equal.

Political party identification shows strong main effects on pandemic-related beliefs across all four of these models. Republicans have lower odds than Democrats of worrying about the health risks from COVID-19, believing the worst of the pandemic is yet to come, and wearing a mask. Both Republicans and Independents are less likely than Democrats to prioritize stopping the spread of the virus versus restarting the economy.

Education $\times$ Party interaction, terms included with these models, have previously shown importance for science-related perceptions on climate change [e.g., McCright and Dunlap, 2011; Hamilton, Hartter, Lemcke-Stampone et al., 2015; Safford, Whitmore and Hamilton, 2020] and other topics, including vaccines [Hamilton, Hartter and Saito, 2015] and trust in the U.S. CDC [Hamilton and Safford, 2021a]. They prove significant with all four of these COVID-19 items, telling us that the effects of education on COVID-19-related beliefs vary with political identity. In the three models where Education $\times$ Republican terms are significant (Worst to Come, Wear Mask, Priority Virus) these interactions describe a convergence with rising education, such that partisans with more education become less far apart. The one model where an Education $\times$ Independent term is significant (Worry Health) likewise indicates convergence, in that instance between Independents and Republicans. This consistent pattern of partisan convergence with rising education runs opposite to the interactions typical of climate change surveys, where partisan differences tend to widen with rising education, so the most-educated partisans stand farthest apart [Drummond and Fischhoff, 2017; Hamilton, 2011; Hamilton, Hartter, Lemcke-Stampone et al., 2015; Kahan, Jenkins-Smith and Braman, 2011; Shao et al., 2014]. The results in Table 2 are consistent, however, with other COVID-19-related analyses, suggesting a different education/party interaction than other science-related issues [Hamilton and Safford, 2021a].

Finally, Table 2 results support the bivariate conclusion from Figure 1 that the most consistent predictor of responses to all four COVID-19 questions is respondents' general belief about how scientists formulate their results. Those who agree that scientists adjust their findings to get the results they want have significantly lower odds of worrying they or their family will get sick from the coronavirus, believing the worst of the COVID-19 pandemic was yet to come, wearing a mask in public, and prioritizing combating the virus over restarting the economy. In short, beliefs about scientists' objectivity strongly relate to views about the seriousness of the pandemic and the actions to combat it. 
Table 3. Predictors of response to whether participants approved of former President Trump's and Governor Sununu's response to COVID-19. Odds ratios are from weighted logit regressions ( $n=1,526$; March and July GS Panel surveys).

\begin{tabular}{|c|c|c|}
\hline & Trump COVID & Sununu COVID \\
\hline Gender & 1.330 & 1.155 \\
\hline Age & 1.023 & $1.028^{* * *}$ \\
\hline Education & $3.192^{* * *}$ & $1.377^{*}$ \\
\hline \multicolumn{3}{|l|}{ Party } \\
\hline \multicolumn{3}{|c|}{ Democrat (base) } \\
\hline Independent & $60.801^{* * *}$ & 1.819 \\
\hline Republican & $609.447^{* * *}$ & $7.225^{* * *}$ \\
\hline \multicolumn{3}{|c|}{ Education $\times$ Party } \\
\hline \multicolumn{3}{|c|}{ Democrat (base) } \\
\hline Independent & $.380^{* *}$ & .970 \\
\hline Republican & $.295^{* * *}$ & $.470^{* *}$ \\
\hline \multicolumn{3}{|l|}{ Survey month } \\
\hline \multicolumn{3}{|l|}{ March (base) } \\
\hline July & $.133^{* * *}$ & 1.065 \\
\hline Scientists Adjust & $2.629^{* * *}$ & 1.054 \\
\hline F Statistic & $24.94^{* * *}$ & $6.82^{* * *}$ \\
\hline
\end{tabular}

Table 3 presents multivariate models for the two political-leader approval questions that appeared on both the March and July surveys. In this two-survey case, we also test for differences by survey month; other predictors are the same as those in Table 2.

Results in Table 3 broadly agree with those in Table 2, while adding more specific information about approval of political leaders. Political-identity effects on approval are strong, as might be expected. Republican respondents were much more likely to approve of these Republican leaders - but Governor Sununu had more bipartisan approval, so the partisan odds ratios in that model are closer to 1. Significant interaction effects again signal partisan convergence with rising education, such that college-educated partisans hold at least somewhat more similar views.

The counter-intuitive negative main effects seen for Education (odds ratios below 1), in Table 3 as in Table 2, call for explanation. At first glance, they appear to suggest that among Democrats (the base category of Party), concern about COVID-19 declines with rising education (in Table 2), while approval of Republican leaders (in Table 3) increases with rising education. As noted earlier, however, the main effects of Education in this case have a specialized interpretation: they describe effects of education while statistically holding constant respondents' views about scientists (Scientists Adjust). If Scientists Adjust were not included among the predictors, the Education main effects in five of the six models would be flat. The single exception is Governor Sununu's approval (Sununu COVID in Table 3), where views about scientists have no effect; approval 
rises with education among Democrats even if we do not control for views about scientists. With or without Scientists Adjust in each model, responses become closer with rising education, so the convergence interpretation is robust.

In the Trump COVID model found in Table 3, as with all four models of Table 2, Scientists Adjust shows strong effects. The more intensely respondents agree that scientists adjust their findings, the more likely they are to approve of President Trump's handling of the pandemic, in which he was openly dismissive of scientists' recommendations. Governor Sununu, in contrast, was considerably more attentive than Trump to scientific advice in formulating his state-level response to COVID-19 [O'Laughlin and Kane, 2020; New Hampshire Governor Chris Sununu, 2020].

Approval of President Trump's actions declined from the March to July surveys: odds of approval dropped by $87 \%$ (multiplied by 0.133 ) between the two waves. Table 3 confirms that approval of Governor Sununu's actions did not change over this period, as shown also by the bivariate analysis in Figure 2d. His pandemic steps included a statewide stay-at-home order and a mask mandate, which contributed to relatively low (by U.S. standards) infection and mortality rates for the state. The Governor also regularly advocated for using scientific data to inform his efforts toward combating the coronavirus. We see that respondent views about scientists' practices correspondingly have no net effects on support for his approach.

The fact that our multivariate analysis uncovered strong effects from beliefs about scientists on views about President Trump's approach, but not Governor Sununu's shows attitudes about the pandemic response were not driven simply by partisan allegiance, but also connect to politicians themselves and the way they engage scientists in policy making. The different effects of Scientists Adjust on the Trump COVID and Sununu COVID variables illustrate that the degree to which politicians embrace or reject science-based planning may be a key factor in shaping assessments of their approaches to combating the COVID-19 pandemic.

COVID-19, partisanship, and the social practice of science
We hypothesized that general beliefs about how scientists develop their results would predict myriad pandemic-related views. Our findings confirm this hypothesis and show that individuals who question the objectivity of scientists are less likely to fear contracting the coronavirus, wear masks to limit its spread, or prioritize combating the virus over restarting the economy. In our models, beliefs about the integrity of scientists' practices is the strongest and most consistent predictor of views about both the threats from COVID-19 and appropriate responses.

Findings from this study build on the emerging literature connecting science views, partisanship, and beliefs about the coronavirus [Aksoy, Eichengreen and Saka, 2020; Allcott et al., 2020; Algara et al., 2021; Brzezinski et al., 2021; Hamilton and Safford, 2021a]. Risk perceptions among GS Panel respondents vary markedly by political party with Republicans being less worried than Democrats about the threat of COVID-19. This lower concern logically leads to their reduced likelihood of wearing masks and believing that the worst of the pandemic is yet to come. Nonetheless, our discovery that there is some convergence in the views of more educated Republicans and Democrats regarding the risks posed by the coronavirus 
and appropriate responses, suggests that support may not hinge solely on partisan identity. This is where extending our analysis to investigate the effects of beliefs about scientists on COVID-19-related views is revealing.

Looking more closely at the questions assessing support for President Trump's and Governor Sununu's approaches to the pandemic connect partisanship and science views and highlight the importance of general beliefs about scientists' objectivity in shaping views about the coronavirus. During 2020, former President Trump repeatedly questioned scientific authority while Governor Sununu looked to scientists for guidance. Logically those who question scientists' objectivity were more likely to approve of the President's approach, while beliefs about scientists' integrity did not have significant effects on views about the Governor's strategy. Both President Trump and Governor Sununu are Republicans, thus it is also logical that Republicans are more likely than Democrats to approve of both leaders' approaches to the pandemic. However, support for Governor Sununu's approach was nearly double that of President Trump (see Figure 2). The variable that helps explain the markedly different levels of support is Scientists Adjust.

The importance of science in guiding policy has never been more apparent than during the COVID-19 crisis. Overall, the focus on science-based approaches has reinforced the authority and key social role of scientists in society. Studies from around the world have shown that trust in science is a key factor affecting understanding of coronavirus-related risks, adoption of preventive measures, and support for science-based policy responses [Breakwell and Jaspal, 2021; Plohl and Musil, 2021; Pagliaro et al., 2021]. While the importance of trust in science transcends borders, what constitutes trust is socially determined. Our findings focused on one dimension of trust in scientists, integrity, are consistent with these global patterns, but also reflect the social context in N.H. and the U.S., further demonstrating how the interpretation of science is culturally situated [Jasanoff, 2011].

The increasingly ideological nature of policy making in the U.S. and beyond has pervaded the coronavirus situation, and this has made separating science from politics challenging. Our study shows that the two factors that are most likely to predict views about all aspects of the COVID-19 pandemic are partisan identity and beliefs about the objectivity of scientists. While political views are often ideological, and thus harder to shift, the belief that scientists adjust their findings to get the answers they want may in part stem from misunderstanding of scientific methods, uncertainty, and the incremental nature of scientific inquiry, thus, offering opportunities for science communicators to address misperceptions.

Finally, it is important to recognize that our study draws upon survey data only from N.H., and with a limited number of questions; thus, we need to be circumspect about the broader generalizability of our findings. Nonetheless, our study provides strong evidence that views about scientists matter. Further research is needed to better understand to what extent the public views the objectivity of scientists from distinct disciplines or institutions differently, how education and partisan identity interconnect and perhaps help transcend ideological differences, and whether perceptions of other dimensions of trust in scientists have similar effects. The COVID-19 pandemic continues to be one of the greatest threats to 
humankind and compliance with risk reduction behaviors, use of vaccines, and acceptance of therapeutics will likely depend on "following scientists" as much as "following the science". Thus, communicating about the rigor of scientific practices and the integrity of scientists will be a critical step toward creating broad support for the science-based approaches needed to stem the tide of COVID-19.

\section{References}

Adolph, C., Amano, K., Bang-Jensen, B., Fullman, N. and Wilkerson, J. (2021). 'Pandemic politics: timing state-level social distancing responses to COVID-19'. Journal of Health Politics, Policy and Law 46 (2), pp. 211-233. https://doi.org/10.1215/03616878-8802162.

Agley, J. and Xiao, Y. (2021). 'Misinformation about COVID-19: evidence for differential latent profiles and a strong association with trust in science'. BMC Public Health 21, 89. https: //doi .org/10.1186/s12889-020-10103-x.

Aksoy, C. G., Eichengreen, B. and Saka, O. (2020). Revenge of the experts: will COVID-19 renew or diminish public trust in science? CEPR Discussion Paper No. DP15447. URL: https://ssrn. com/abstract=3737580.

Algara, C., Fuller, S., Hare, C. and Kazemian, S. (2021). 'The interactive effects of scientific knowledge and gender on COVID-19 social distancing compliance'. Social Science Quarterly 102 (1), pp. 7-16. https://doi.org/10.1111/ssqu.12894.

Allcott, H., Boxell, L., Conway, J., Gentzkow, M., Thaler, M. and Yang, D. (2020). Polarization and public health: partisan differences in social distancing during the coronavirus pandemic. NBER Working Paper No. w26946.

URL: https: //ssrn . com/abstract=3574415.

Bauer, M. W. and Jensen, P. (2011). 'The mobilization of scientists for public engagement'. Public Understanding of Science 20 (1), pp. 3-11. https://doi.org/10.1177/0963662510394457.

Besley, J. C., Lee, N. M. and Pressgrove, G. (2021). 'Reassessing the variables used to measure public perceptions of scientists'. Science Communication 43 (1), pp. 3-32. https://doi.org/10.1177/1075547020949547.

Besley, J. C. and Nisbet, M. (2013). 'How scientists view the public, the media and the political process'. Public Understanding of Science 22 (6), pp. 644-659. https://doi.org/10.1177/0963662511418743.

Breakwell, G. M. and Jaspal, R. (2021). 'Identity change, uncertainty and mistrust in relation to fear and risk of COVID-19'. Journal of Risk Research 24 (3-4), pp.335-351. https://doi.org/10.1080/13669877.2020.1864011.

Brewer, P. R. and Ley, B. L. (2013). 'Whose science do you believe? Explaining trust in sources of scientific information about the environment'. Science Communication 35 (1), pp. 115-137. https://doi.org/10.1177/1075547012441691.

Brossard, D. and Nisbet, M. C. (2007). 'Deference to scientific authority among a low information public: understanding U.S. opinion on agricultural biotechnology'. International Journal of Public Opinion Research 19 (1), pp. 24-52. https://doi.org/10.1093/ijpor/edl003.

Brzezinski, A., Kecht, V., Van Dijcke, D. and Wright, A. L. (2021). Science skepticism reduces compliance with COVID-19 shelter-in-place policies. University of Chicago, Becker Friedman Institute for Economics Working Paper No. 2020-56. https://doi.org/10.2139/ssrn. 3587990.

Calvillo, D. P., Ross, B. J., Garcia, R. J. B., Smelter, T. J. and Rutchick, A. M. (2020). 'Political ideology predicts perceptions of the threat of COVID-19 (and susceptibility to fake news about it)'. Social Psychological and Personality Science 11 (8), pp. 1119-1128. https://doi.org/10.1177/1948550620940539. 
Chryssochoidis, G., Strada, A. and Krystallis, A. (2009). 'Public trust in institutions and information sources regarding risk management and communication: towards integrating extant knowledge'. Journal of Risk Research 12 (2), pp. 137-185. https://doi.org/10.1080/13669870802637000.

Collins, H. M. and Evans, R. (2002). 'The third wave of science studies: studies of expertise and experience'. Social Studies of Science 32 (2), pp. 235-296. https://doi.org/10.1177/0306312702032002003.

De Vries, R., Anderson, M. S. and Martinson, B. C. (2006). 'Normal misbehavior: scientists talk about the ethics of research'. Journal of Empirical Research on Human Research Ethics 1 (1), pp. 43-50. https://doi.org/10.1525/jer.2006.1.1.43.

Drummond, C. and Fischhoff, B. (2017). 'Individuals with greater science literacy and education have more polarized beliefs on controversial science topics'. Proceedings of the National Academy of Sciences 114 (36), pp. 9587-9592. https://doi.org/10.1073/pnas.1704882114.

Eichengreen, B., Aksoy, C. G. and Saka, O. (2021). 'Revenge of the experts: will COVID-19 renew or diminish public trust in science?' Journal of Public Economics 193, 104343. https://doi.org/10.1016/j.jpubeco.2020.104343.

Fiske, S. T. and Dupree, C. (2014). 'Gaining trust as well as respect in communicating to motivated audiences about science topics'. Proceedings of the National Academy of Sciences 111 (Supplement 4), pp. 13593-13597. https://doi.org/10.1073/pnas.1317505111.

Fogg, L. M., Hamilton, L. C. and Bell, E. S. (2020). 'Views of the highway: infrastructure reality, perceptions, and politics'. SAGE Open 10 (4). https://doi .org/10.1177/2158244020963609.

Funk, C., Hefferon, M., Kennedy, B. and Johnson, C. (2019). 'Trust and mistrust in Americans' views of scientific experts'. Pew Research Center.

URL: https://www . pewresearch.org/science/2019/08/02/trust-and-mistru st-in-americans-views-of-scientific-experts/.

Gadarian, S. K., Goodman, S. W. and Pepinsky, T. B. (2021). 'Partisanship, health behavior, and policy attitudes in the early stages of the COVID-19 pandemic'. PLoS ONE 16 (4), e0249596. https://doi.org/10.1371/journal . pone. 0249596.

Gauchat, G. (2012). 'Politicization of science in the public sphere: a study of public trust in the United States, 1974 to 2010'. American Sociological Review 77 (2), pp. 167-187. https://doi.org/10.1177/0003122412438225.

Gieryn, T. F. (1983). 'Boundary-work and the demarcation of science from non-science: strains and interests in professional ideologies of scientists'. American Sociological Review 48 (6), pp. 781-795. https://doi.org/10.2307/2095325.

Green, J., Edgerton, J., Naftel, D., Shoub, K. and Cranmer, S. J. (2020). 'Elusive consensus: polarization in elite communication on the COVID-19 pandemic'. Science Advances 6 (28), eabc2717. https://doi .org/10.1126/sciadv . abc2717.

Grossman, G., Kim, S., Rexer, J. and Thirumurthy, H. (2020). 'Political partisanship influences behavioral responses to governors' recommendations for COVID-19 prevention in the United States'. Proceedings of the National Academy of Sciences 117 (39), pp. 24144-24153. https: //doi .org/10.1073/pnas . 2007835117. URL: https : //ssrn. com/abstract=3578695.

Hamilton, L. C. (2011). 'Education, politics and opinions about climate change evidence for interaction effects'. Climatic Change 104 (2), pp. 231-242. https://doi.org/10.1007/s10584-010-9957-8. 
Hamilton, L. C. and Fogg, L. M. (2019). Physical-world knowledge and public views on climate change. Faculty Publications. Durham, NH, U.S.A.: University of New Hampshire. URL: https://scholars . unh. edu/faculty_pubs/648.

Hamilton, L. C., Hartter, J., Lemcke-Stampone, M., Moore, D. W. and Safford, T. G. (2015). 'Tracking public beliefs about anthropogenic climate change'. PLoS ONE 10 (9), e0138208. https://doi.org/10.1371/journal . pone. 0138208.

Hamilton, L. C., Hartter, J. and Saito, K. (2015). 'Trust in scientists on climate change and vaccines'. SAGE Open 5 (3). https: //doi .org/10 .1177/2158244015602752.

Hamilton, L. C. and Safford, T. G. (2020a). Ideology affects trust in science agencies during a pandemic. Carsey Perspectives. Durham, NH, U.S.A.: Carsey School of Public Policy, University of New Hampshire. https://doi.org/10.34051/p/2020.389.

- (2020b). Trusting scientists more than the government: New Hampshire perceptions of the pandemic. Carsey Perspectives. Durham, NH, U.S.A.: Carsey School of Public Policy, University of New Hampshire. https://doi.org/10.34051/p/2020.397.

- (2021a). 'Elite cues and the rapid decline in trust in science agencies on COVID-19'. Sociological Perspectives. https://doi.org/10.1177/07311214211022391.

- (2021b). The worst is behind us: news media choice and false optimism in the summer of 2020. Faculty Publications. Durham, NH, U.S.A.: University of New Hampshire. URL: https://scholars.unh.edu/faculty_pubs/1001.

- (2021c). The worst is behind us: news media choice and false optimism in the summer of 2020. Academia Letters. https://doi .org/10.20935/AL232.

Iyengar, S. and Massey, D. S. (2019). 'Scientific communication in a post-truth society'. Proceedings of the National Academy of Sciences 116 (16), pp. 7656-7661. https://doi.org/10.1073/pnas.1805868115.

Jasanoff, S. (2011). 'Cosmopolitan knowledge: climate science and global civic epistemology'. In: The Oxford handbook of climate change and society. Ed. by J. S. Dryzek, R. B. Norgaard and D. Schlosberg. Oxford, U.K.: Oxford University Press, pp. 129-143. https://doi.org/10.1093/oxfordhb/9780199566600.003.0009.

Kahan, D. M., Jenkins-Smith, H. and Braman, D. (2011). 'Cultural cognition of scientific consensus'. Journal of Risk Research 14 (2), pp. 147-174. https://doi.org/10.1080/13669877.2010.511246.

Kellstedt, P. M., Zahran, S. and Vedlitz, A. (2008). 'Personal efficacy, the information environment, and attitudes toward global warming and climate change in the United States'. Risk Analysis 28 (1), pp. 113-126. https://doi.org/10.1111/j.1539-6924.2008.01010.x.

König, L. and Breves, P. (2021). 'Providing health information via Twitter: professional background and message style influence source trustworthiness, message credibility and behavioral intentions'. JCOM 20 (04), A04. https://doi.org/10.22323/2.20040204.

König, L. and Jucks, R. (2019). 'Hot topics in science communication: aggressive language decreases trustworthiness and credibility in scientific debates'. Public Understanding of Science 28 (4), pp. 401-416. https://doi.org/10.1177/0963662519833903.

Kreps, S. E. and Kriner, D. L. (2020). 'Model uncertainty, political contestation, and public trust in science: evidence from the COVID-19 pandemic'. Science Advances 6 (43), eabd4563. https://doi.org/10.1126/sciadv . abd4563. 
Kreps, S., Prasad, S., Brownstein, J. S., Hswen, Y., Garibaldi, B. T., Zhang, B. and Kriner, D. L. (2020). 'Factors associated with US adults' likelihood of accepting COVID-19 vaccination'. JAMA Network Open 3 (10), e2025594.

https://doi.org/10.1001/jamanetworkopen.2020.25594.

Leiserowitz, A. A., Maibach, E. W., Roser-Renouf, C., Smith, N. and Dawson, E. (2013). 'Climategate, public opinion, and the loss of trust'. American Behavioral Scientist 57 (6), pp. 818-837. https : //doi .org/10.1177/0002764212458272.

Mayer, R. C., Davis, J. H. and Schoorman, F. D. (1995). 'An integrative model of organizational trust'. The Academy of Management Review 20 (3), pp. 709-734. https://doi.org/10.2307/258792.

McCright, A. M. and Dunlap, R. E. (2011). 'The politicization of climate change and polarization in the American public's views of global warming, 2001-2010'. The Sociological Quarterly 52 (2), pp. 155-194. https://doi.org/10.1111/j.1533-8525.2011.01198.x.

McFadden, S. M., Malik, A. A., Aguolu, O. G., Willebrand, K. S. and Omer, S. B. (2020). 'Perceptions of the adult US population regarding the novel coronavirus outbreak'. PLoS ONE 15 (4), e0231808. https://doi.org/10.1371/journal.pone.0231808.

Merkley, E. (2020). 'Anti-intellectualism, populism, and motivated resistance to expert consensus'. Public Opinion Quarterly 84 (1), pp. 24-48. https://doi.org/10.1093/poq/nfz053.

Millstone, E. and van Zwanenberg, P. (2000). 'A crisis of trust: for science, scientists or for institutions?' Nature Medicine 6 (12), pp. 1307-1308. https://doi.org/10.1038/82102.

Motta, M. (2018a). 'The dynamics and political implications of anti-intellectualism in the United States'. American Politics Research 46 (3), pp. 465-498. https://doi.org/10.1177/1532673x17719507.

- (2018b). 'The polarizing effect of the March for Science on attitudes toward scientists'. Political Science \& Politics 51 (4), pp. 782-788. https://doi.org/10.1017/s1049096518000938.

National Academies of Sciences, Engineering, and Medicine (NASEM) (2009). On being a scientist: a guide to responsible conduct in research. 3 rd ed. Washington, DC, U.S.A.: The National Academies Press. https://doi.org/10.17226/12192.

New Hampshire Governor Chris Sununu (1st May 2020). Governor Chris Sununu announces stay at home 2.0. URL: https://www . governor.nh.gov/news-and-medi a/governor-chris-sununu-announces-stay-home-20.

O'Laughlin, F. and Kane, E. (1st May 2020). 'Sununu extends New Hampshire's stay-at-home order through end of May'. News Boston.

URL: https://whdh.com/news/sununu-extends-new-hampshires-stay-at-hom e-order-through-end-of-may/.

Pagliaro, S., Sacchi, S., Pacilli, M. G., Brambilla, M., Lionetti, F., Bettache, K., Bianchi, M., Biella, M., Bonnot, V., Boza, M., Butera, F., Ceylan-Batur, S., Chong, K., Chopova, T., Crimston, C. R., Álvarez, B., Cuadrado, I., Ellemers, N., Formanowicz, M., Graupmann, V., Gkinopoulos, T., Hye Kyung Jeong, E., Jasinskaja-Lahti, I., Jetten, J., Muhib Bin, K., Mao, Y., McCoy, C., Mehnaz, F., Minescu, A., Sirlopú, D., Simić, A., Travaglino, G., Uskul, A. K., Zanetti, C., Zinn, A. and Zubieta, E. (2021). 'Trust predicts COVID-19 prescribed and discretionary behavioral intentions in 23 countries'. PLOS ONE 16 (3), e0248334. https://doi.org/10.1371/journal.pone.0248334. 
Plohl, N. and Musil, B. (2021). 'Modeling compliance with COVID-19 prevention guidelines: the critical role of trust in science'. Psychology, Health $\mathcal{E}$ Medicine 26 (1), pp. 1-12. https://doi.org/10.1080/13548506.2020.1772988.

Post, S., Bienzeisler, N. and Lohöfener, M. (2021). 'A desire for authoritative science? How citizens' informational needs and epistemic beliefs shaped their views of science, news, and policymaking in the COVID-19 pandemic'. Public Understanding of Science 30 (5), pp. 496-514. https://doi.org/10.1177/09636625211005334.

Prasad, A. (2021). 'Anti-science misinformation and conspiracies: COVID-19, post-truth, and science \& technology studies (STS)'. Science, Technology and Society. https://doi.org/10.1177/09717218211003413.

Renn, O. and Levine, D. (1991). 'Credibility and trust in risk communication'. In: Communicating risks to the public: international perspectives. Ed. by R. E. Kasperson and P. J. M. Stallen. Vol. 4. Technology, Risk, and Society (An International Series in Risk Analysis). Dordrecht, The Netherlands: Springer, pp. 175-217. https://doi .org/10.1007/978-94-009-1952-5_10.

Safford, T. G. and Hamilton, L. C. (2020). Views of a fast-moving pandemic: a survey of granite staters' responses to COVID-19. Carsey Perspectives. Durham, NH, U.S.A.: Carsey School of Public Policy, University of New Hampshire. https://doi.org/10.34051/p/2020.393.

Safford, T. G., Hamilton, L. C. and Whitmore, E. (2017). The Zika virus threat: how concerns about scientists may undermine efforts to combat the pandemic. Carsey Research. Regional Issue Brief \#49. Durham, NH, U.S.A.: Carsey School of Public Policy, University of New Hampshire. https://doi.org/10.34051/p/2020.288.

Safford, T. G., Norman, K. C., Henly, M., Mills, K. E. and Levin, P. S. (2014). 'Environmental awareness and public support for protecting and restoring Puget Sound'. Environmental Management 53 (4), pp. 757-768. https://doi.org/10.1007/s00267-014-0236-8.

Safford, T. G., Whitmore, E. H. and Hamilton, L. C. (2020). 'Questioning scientific practice: linking beliefs about scientists, science agencies, and climate change'. Environmental Sociology 6 (2), pp. 194-206. https://doi.org/10.1080/23251042.2019.1696008.

Sanchez, C. and Dunning, D. (2021). 'The anti-scientists bias: the role of feelings about scientists in COVID-19 attitudes and behaviors'. Journal of Applied Social Psychology 51 (4), pp. 461-473. https://doi .org/10.1111/jasp. 12748.

Shao, W., Keim, B. D., Garand, J. C. and Hamilton, L. C. (2014). 'Weather, climate, and the economy: explaining risk perceptions of global warming, 2001-10'. Weather, Climate, and Society 6 (1), pp. 119-134. https://doi.org/10.1175/wcas-d-13-00029.1.

Sides, J., Tausanovitch, C. and Vavreck, L. (2020). 'The politics of COVID-19: partisan polarization about the pandemic has increased, but support for health care reform hasn't moved at all'. Harvard Data Science Review Special Issue 1 COVID-19: Unprecedented challenges and chances. https://doi.org/10.1162/99608f92.611350fd.

Sieber, J. E. and Tolich, M. B. (2013). Planning ethically responsible research. 2nd ed. Vol. 31. Applied Social Research Methods Series. Thousand Oaks, CA, U.S.A.: SAGE Publications. https : //doi .org/10.4135/9781506335162.

Vraga, E., Myers, T., Kotcher, J., Beall, L. and Maibach, E. (2018). 'Scientific risk communication about controversial issues influences public perceptions of scientists' political orientations and credibility'. Royal Society Open Science 5 (2), 170505. https://doi.org/10.1098/rsos.170505. 
Wynne, B. (1995). 'Public understanding of science'. In: Handbook of science and technology studies. Ed. by S. Jasanoff, G. E. Markle, J. C. Petersen and T. Pinch. Thousand Oaks, CA, U.S.A.: SAGE Publications, pp. 361-368.

https://doi.org/10.4135/9781412990127.

Yamamoto, Y. T. (2012). 'Values, objectivity and credibility of scientists in a contentious natural resource debate'. Public Understanding of Science 21 (1), pp. 101-125. https://doi.org/10.1177/0963662510371435.

Authors

How to cite

Safford, T. G., Whitmore, E. H. and Hamilton, L. C. (2021). 'Follow the scientists? How beliefs about the practice of science shaped COVID-19 views'.

JCOM 20 (07), A03. https:/ / doi.org/10.22323/2.20070203.

(C) The Author(s). This article is licensed under the terms of the Creative Commons

Attribution - NonCommercial - NoDerivativeWorks 4.0 License.

ISSN 1824-2049. Published by SISSA Medialab. jcom.sissa.it 